\title{
Sex ratios of juvenile loggerhead sea turtles Caretta caretta in the Mediterranean Sea
}

\author{
Paolo Casale ${ }^{1, *}$, Bojan Lazar ${ }^{2,3}$, Sara Pont ${ }^{4}$, Jesús Tomás ${ }^{5}$, Nicola Zizzo ${ }^{6}$, \\ Ferran Alegre ${ }^{4}$, Javier Badillo ${ }^{5}$, Aldo Di Summa ${ }^{6}$, Daniela Freggi ${ }^{7}$, \\ Gordana Lacković ${ }^{8}$, Juan Antonio Raga ${ }^{5}$, Lucio Rositani ${ }^{9}$, Nikola Tvrtković ${ }^{2}$ \\ ${ }^{1}$ via Antonio Calderara 29, 00125 Roma, Italy \\ ${ }^{2}$ Department of Zoology, Croatian Natural History Museum, Demetrova 1, 10000 Zagreb, Croatia \\ ${ }^{3}$ Blue World Institute of Marine Research and Conservation, Kaštel 24, 51551 Veli Lošinj, Croatia \\ ${ }^{4}$ Foundation for the Conservation and Recovery of Marine Animals, Camí Ral, 239 Premià de Mar, 08330 Barcelona, Spain \\ ${ }^{5}$ Marine Zoology Unit, Cavanilles Institute of Biodiversity and Evolutionary Biology, University of Valencia, PO Box 22085, \\ 46071 Valencia, Spain \\ ${ }^{6}$ Department of Animal Health and Well-Being, University of Bari, SP per Casamassima km 3, 70010 Valenzano, Italy \\ ${ }^{7}$ Sea Turtle Rescue Centre, WWF Italy, CP 92010 Lampedusa, Italy \\ ${ }^{8}$ Department of Zoology, Faculty of Science, University of Zagreb, 6 Roosevelt Square, 10000 Zagreb, Croatia \\ ${ }^{9}$ Laboratorio Biologia Marina Bari, Molo Pizzoli, Porto di Bari, 70100 Bari, Italy
}

\begin{abstract}
Species with environmental sex determination may show sex ratios that differ from 1:1; therefore, sex ratio is an important variable when studying the population dynamics of these species. For instance, when estimating population size and productivity, sex ratio would be a required parameter. For endangered species, such as sea turtles, this is particularly important in order to understand the possible effects of human impacts and conservation measures. Unfortunately, only adult sea turtles show evident external sexual dimorphism; sex ratios are more difficult to obtain for the juvenile class, which represents the largest part of a population. Here we present the first extensive assessment of the sex ratio of juvenile loggerhead turtles Caretta caretta in the Mediterranean Sea. A total of 310 dead turtles from 4 different areas were sexed by direct examination of gonads, the most reliable sexing method. Females comprised $54.2 \%$ of the whole sample, and no significant differences were observed among study areas. However, this value cannot be ascribed to a single population, because specimens from different nesting sites - both within and outside the Mediterranean-share the same foraging areas, and each population may potentially contribute a different sex ratio. Although we recorded an unbiased sex ratio, our results were compatible with a hypothetical scenario in which Mediterranean nesting beaches produce a majority of females when other information from the region (distribution, mixed stocks and sex ratios) was considered.
\end{abstract}

KEY WORDS: Sex ratio $\cdot$ Caretta caretta $\cdot$ Mediterranean $\cdot$ Juvenile sea turtles

Resale or republication not permitted without written consent of the publisher

\section{INTRODUCTION}

As in many other reptiles (Janzen \& Paukstis 1991), the sex of sea turtles is determined by the temperature to which an embryo is exposed during its development. The point at which a balanced sex ratio occurs is known as the pivotal temperature; in sea turtles, more females result from temperatures above the pivotal temperature and more males from cooler temperatures (see Wibbels 2003 for a review).

As a general consequence, skewed sex ratios are more common in species with temperature-dependent sex determination (TSD) than in species with a genotypic sex determination (Bull 1980). For this reason, the sex ratio must also be considered in population dynamics of species with TSD. Important parameters such as 
population size and productivity can only be correctly estimated if the sex ratio is known. Since all species of sea turtles are threatened, this is particularly important for our understanding of how they may respond to both anthropogenic effects and conservation measures. Unfortunately, sex ratio is not easy to assess in sea turtles, and this leads to increased uncertainty in population models. An understanding of natural sex ratios and possible sex ratio variability among species and populations is also important in our understanding of the evolutionary basis of environmental sex determination (Mrosovsky 1994).

For convenience, 3 major life-stages (hatchlings, juveniles, and adults) can be distinguished in sea turtles; a different method is used to investigate sex ratios at each stage. Hatchling sex ratio is obtained directly, through examination of gonads of hatchlings sampled at nesting beaches (e.g. Yntema \& Mrosovsky 1980), or indirectly, estimated from nest temperature (e.g. Standora \& Spotila 1985) or other variables associated with nest temperature such as incubation duration (e.g. Mrosovsky et al. 1999). Although hatchlings can be sampled on land, other life stages must be sampled at sea. Adults are easily differentiated because of their external sexual dimorphism (Casale et al. 2005a). Juvenile sex ratio is the most difficult to obtain, owing to both the at-sea sampling requirement and the absence of sexual dimorphism. Sex ratio can be determined by blood hormonal dosage (Owens et al. 1978), observation of gonads by laparoscopy (Wood et al. 1983), or necropsy (Work 2000) in the case of dead animals. Juveniles represent the greatest part of the population and a pool of many cohorts, so an assessment of their sex ratio is of particular importance.

Investigations of the sex ratio of all 3 classes of loggerhead turtles (hatchlings, juveniles, and adults) have recently begun in the Mediterranean region, but so far lack results that can be considered as conclusive at the population scale. Hatchling sex ratio was skewed towards females in estimations from Cyprus, Turkey (Kaska et al. 1998, Godley et al. 2001a) and Greece (Rees \& Margaritoulis 2004, Zbinden et al. 2006). Available data on incubation duration (shorter incubation periods result from higher nest temperatures, suggesting a female bias, and vice versa) from monitored nesting beaches in the Mediterranean suggest a heterogeneous situation. Female-biased sex ratios are probably common in most years and at most sites, but balanced or even male-biased sex ratios probably occur in at least some years and at some sites (Godley et al. 2001b). These data show that about $53 \%$ of monitored nests are laid in beaches where incubation temperatures are probably above the pivotal temperature. The nesting situation in Libya remains unclear. An unknown, but perhaps substantial, number of nests are laid in Libya along a very extensive tract of coast (Laurent et al. 1998a). The only incubation duration data available from Libya suggest a female-biased sex ratio, but this may not be representative as it was based on only 5 nests (Margaritoulis et al. 2003). The Libyan coast is the southernmost turtle nesting area in the Mediterranean, and the high temperatures required for a female-biased sex ratio are theoretically possible. In summary, existing data are insufficient to facilitate estimation of the overall sex ratio of Mediterranean loggerhead hatchling production; however, they are suggestive of a female predominance.

For adults, the only data available for the Mediterranean also suggest a predominance of females $(77 \%$; Casale et al. 2005a). A preliminary study of juveniles in the central Mediterranean estimated a sex ratio of $\sim 1: 1$ ( $55 \%$ females), but this was based on an indirect approach (blood testosterone levels) and could not be considered as conclusive (Casale et al. 1998).

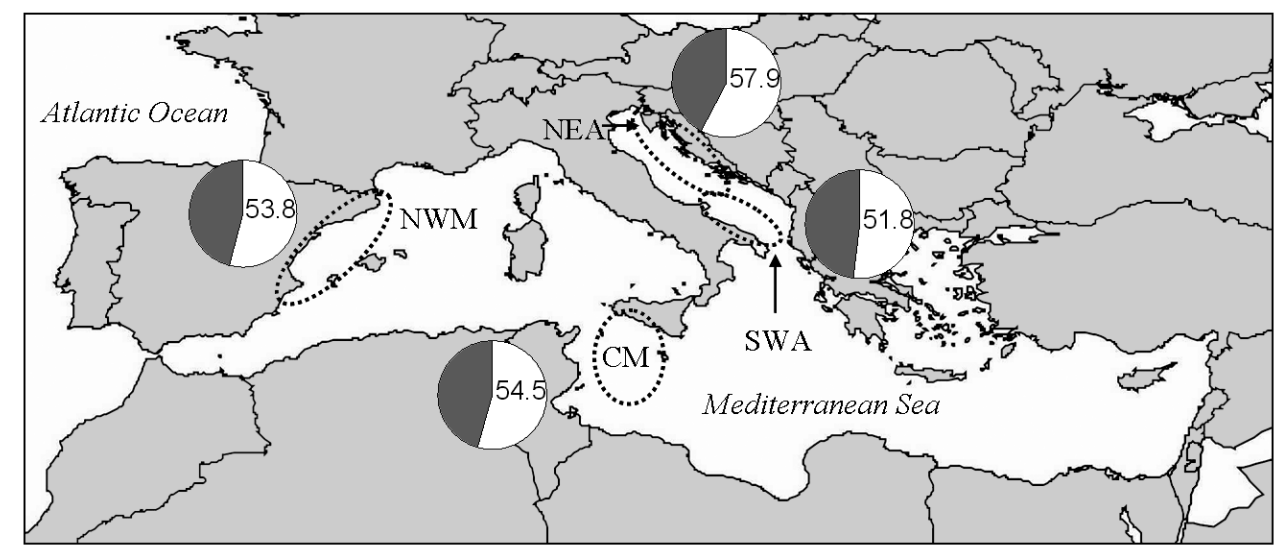

Fig. 1. Sampling areas. NWM: north-west Mediterranean; CM: central Mediterranean; SWA: south-west Adriatic; NEA: northeast Adriatic; \% female Caretta caretta observed in each area is shown 


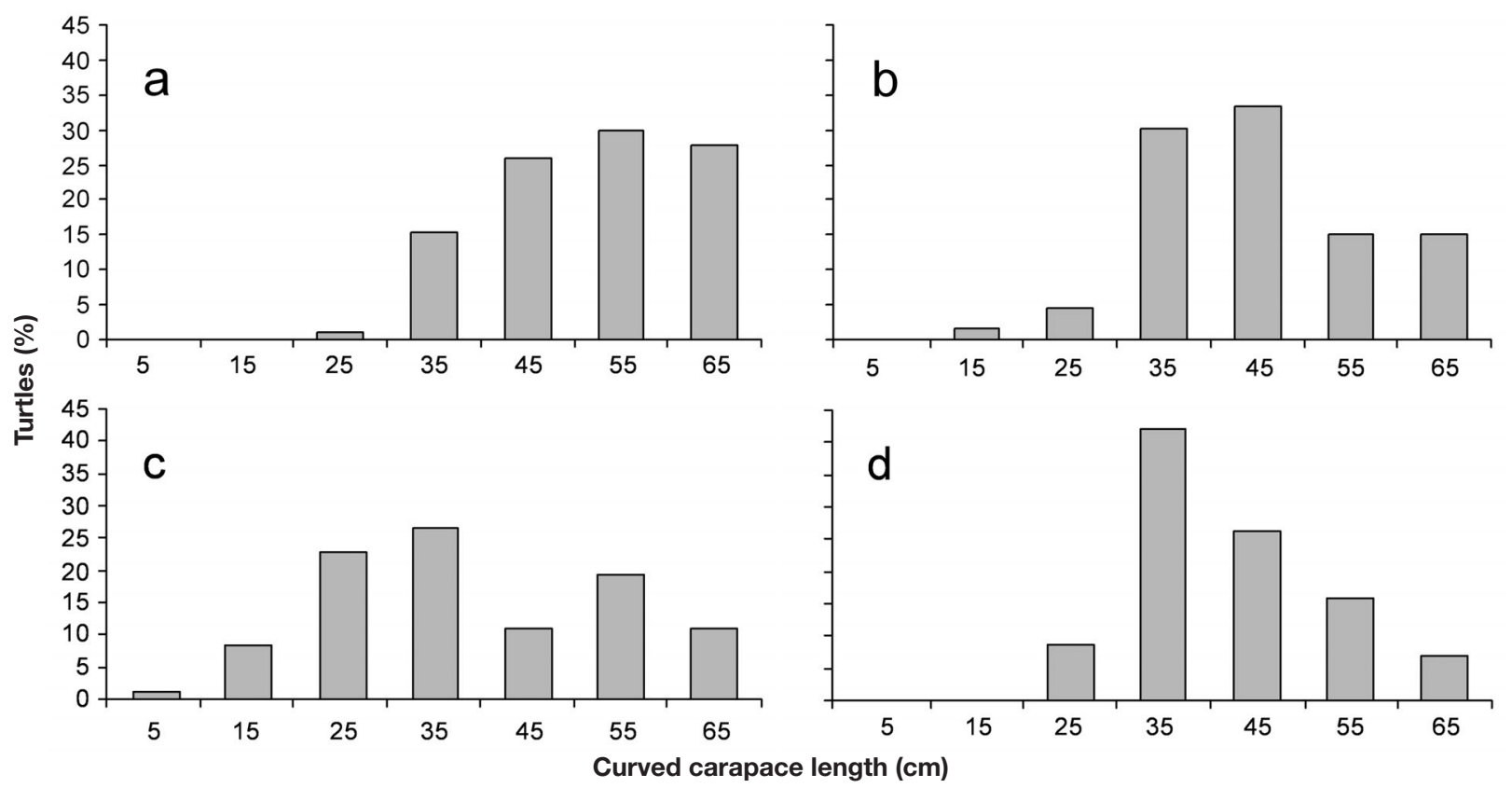

Fig. 2. Caretta caretta. Size distribution (cm curved carapace length notch-to-tip) of turtles in 4 study areas: (a) north-west Mediterranean $(n=104)$, (b) central Mediterranean $(n=66)$, (c) south-west Adriatic $(n=83)$, (d) north-east Adriatic $(n=57)$; total $n=310$

The present study aimed to provide the first estimations of sex ratios of juvenile loggerhead turtles from different Mediterranean areas using the most reliable method: direct examination of gonads.

\section{MATERIALS AND METHODS}

We examined 310 dead immature loggerhead sea turtles captured by fishing gear (longline, trawl, static net), found floating at sea or stranded between 1986 and 2005. Turtles were collected from 4 different areas of the Mediterranean Sea (Fig. 1): the north-west Mediterranean (Spain, Catalonia and Valencia regions; $\mathrm{n}=104$ ); central Mediterranean (Italy; $\mathrm{n}=66$ ); the south-west Adriatic (Italy; $\mathrm{n}=83$ ); and the northeast Adriatic (Croatia and Slovenia; $\mathrm{n}=57$ ).

Sex was determined through direct examination of the gonads, which exhibit sex-specific differences in both external morphology and histology (e.g. Yntema \& Mrosovsky 1980, Wyneken 2001, Wibbels 2003). In most cases gonad morphology was examined during necropsy, while in some cases via removal of gonads for examination under a dissecting microscope and in other cases through histological analysis.

In order to assess possible age/size-dependent sex ratios, we arbitrarily subdivided the sample into 2 size classes: $\leq 40$ and $>40 \mathrm{~cm}$ curved carapace length notch-to-tip (CCL n-t) (Bolten 1999).

Confidence intervals (CI) for sex ratios were calculated using the method for binomial distribution (Zar 1999).

\section{RESULTS}

The overall proportion of females was $54.2 \%$ (CI $95 \%$ : 48.5 to $59.8 \%$; $=310$ ), with no significant difference observed among the 4 study areas $\left(\chi^{2}=0.51 ; \mathrm{p}=\right.$ 0.92; $\mathrm{n}=310$ ) (Fig. 1). In 3 of the areas, sex ratios of the 2 size classes ( $\leq 40$ and $>40 \mathrm{~cm}$ CCL $\mathrm{n}$-t) did not differ significantly. In the north-west Mediterranean, a lower proportion of females was observed among small specimens $(29.4 \%)$ than among larger turtles (58.6\%) (Fisher's exact test; $\mathrm{p}<0.05 ; \mathrm{n}=104$ ). The size distribution (cm CCL $\mathrm{n}-\mathrm{t}$ ) of combined sexes from each area is shown in Fig. 2.

\section{DISCUSSION}

When investigating the sex ratio of juveniles, it should be taken into account that different populations may share a common foraging area. Thus, the observed sex ratio might actually represent that of different contributions of these mixing populations.

The basin-wide distribution of loggerhead sea turtles originating from various Mediterranean and Atlantic nesting sites remains poorly understood.

At present, the following information is available from the 4 areas sampled in this study. The western Mediterranean is frequented by both Mediterranean and Atlantic specimens (Laurent et al. 1998b). The central Mediterranean is frequented by turtles from Greece (Margaritoulis et al. 2003), Cyprus (A. Broder- 
ick \& B. Godley pers. comm.), and the Atlantic (Laurent et al. 1998b). The southern Adriatic seems likely to be frequented by oceanic-stage juveniles, probably from adjacent Greek nesting sites (Casale et al. 2005b), but turtles from the Atlantic can reach this area too (Manzella et al. 1988, Argano et al. 1992). The northern Adriatic is frequented by turtles from Greece (Margaritoulis et al. 2003, Lazar et al. 2004). Therefore, the overall juvenile sex ratio recorded in this study is likely to be a combination of sex ratios from several Atlantic and Mediterranean populations.

Since the sex ratio of Atlantic specimens entering the Mediterranean is probably male-biased (Casale et al. 2002 ), the sex ratio of $\sim 1: 1$ reported here would imply that the sex ratio of Mediterranean juveniles, or at least of those from some nesting sites, is female-biased. This scenario would explain why a higher proportion of males was observed among small specimens in the north-west Mediterranean but not among those from other study areas. In fact, based upon the modal size of loggerhead sea turtles captured in the Azores (around $30 \mathrm{~cm}$ CCL n-t; Bjorndal et al. 2000), we can assume that Atlantic specimens enter the western Mediterranean at a small size. They then disperse into the central Mediterranean (Laurent et al. 1998b) and perhaps even further eastwards, reaching a larger size during this dispersal (a sea turtle from the Gulf of Mexico was re-encountered in the mouth of the Adriatic Sea at a size of $43.5 \mathrm{~cm}$ CCL n-t; Manzella et al. 1988). The absence of Atlantic specimens among adults observed in the Mediterranean (Laurent et al. 1998b) suggests that these turtles eventually leave this region at a certain size. These Atlantic specimens would be predominantly males, and their departure from the Mediterranean agrees well with the observed female-biased sex ratio among Mediterranean adults $(77 \%$; Casale et al. 2005a). It is interesting that this adult sex ratio is similar to the hatchling sex ratios estimated from the 2 most important nesting sites assessed in the Mediterranean (Margaritoulis et al. 2003), which were also those closest to our study areas: Zakynthos (75\%; Zbinden et al. 2006) and Kyparissia Bay (70\%; Rees \& Margaritoulis 2004) (western Greece). This also supports the hypothesis that the observed $\sim 1: 1$ sex ratio of juveniles in our study might not be exclusively indicative of the Mediterranean stock, but may also include juvenile loggerhead sea turtles of Atlantic origin.

Our study demonstrates that investigation of the sex ratio of species with a complex life history, such as sea turtles, is not a simple task. This is particularly true when individuals from different nesting sites share the same marine habitats, at least for a portion of their life-cycle. Hence, in addition to collecting simple data on sex, interpretation of sex ratios requires additional knowledge on distribution, movement and origin of sea turtles.
Acknowledgements. We thank the Conselleria de Territorio y Vivienda of the Generalitat Valenciana and the staff of the Marine Zoology Unit of the Cavanilles Research Institute of Biodiversity and Evolutionary Biology (University of Valencia) for their assistance with the north-west Mediterranean part of this study. In the north-east Adriatic, this study was conducted within Research Projects 183007 and 0119164 of the Ministry of Science, Education and Sport (Croatia), and with permits from the Ministry of Environmental, Protection and Physical Planning (Croatia) and Ministry of Environment, Spatial Planning and Energy (Slovenia). We are grateful to V. Îiİa, L. Lipej, R. Turk, R. Graãan and colleagues from the Department of Zoology, Croatian Natural History Museum and Blue World Institute of Marine Research and Conservation for assistance with data collection. We also thank 3 referees for their useful comments on an earlier version of the manuscript and M. White for English revision.

\section{LITERATURE CITED}

Argano R, Basso R, Cocco M, Gerosa G (1992) New data on loggerhead (Caretta caretta) movements within the Mediterranean. Boll Mus Ist Biol Univ Genova 56-57: 137-164

Bjorndal K, Bolten AB, Martins HR (2000) Somatic growth model of juvenile loggerhead sea turtles Caretta caretta: duration of pelagic stage. Mar Ecol Prog Ser 202:265-272

Bolten AB (1999) Techniques for measuring sea turtles. In: Eckert KL, Bjorndal KA, Abreu-Grobois FA, Donnelly M (eds) Research and management techniques for the conservation of sea turtles. IUCN/SSC Mar Turtle Spec Group Publ 4, Washington, DC, p 110-114

Bull JJ (1980) Sex determination in reptiles. Q Rev Biol 55: $3-21$

Casale P, Gerosa G, Argano R, Barbaro S, Fontana G (1998) Testosterone titers of immature loggerhead sea turtles (Caretta caretta) incidentally caught in the central Mediterranean: a preliminary sex ratio study. Chel Conserv Biol 3:90-93

Casale P, Laurent L, Gerosa G, Argano R (2002) Molecular evidence of male-biased dispersal in loggerhead turtle juveniles. J Exp Mar Biol Ecol 267:139-145

Casale P, Freggi D, Basso R, Argano R (2005a) Size at male maturity, sexing methods and adult sex ratio in loggerhead turtles (Caretta caretta) from Italian waters investigated through tail measurements. J Herpetol 15:145-148

Casale P, Freggi D, Basso R, Argano R (2005b) Oceanic habitats for loggerhead turtles (Caretta caretta) in the Mediterranean Sea. Mar Turt Newsl 107:10-11

Godley BJ, Broderick AC, Mrosovsky N (2001a) Estimating hatchling sex ratios of loggerhead turtles in Cyprus from incubation durations. Mar Ecol Prog Ser 21:195-201

Godley BJ, Broderick AC, Downie JR, Glen F, Houghton JD, Kirkwood I, Reece S, Hays GC (2001b) Thermal conditions in nests of loggerhead turtles: further evidence suggesting female skewed sex ratios of hatchling production in the Mediterranean. J Exp Mar Biol Ecol 263:45-63

Janzen FJ, Paukstis GL (1991) Environmental sex determination in reptiles: ecology, evolution, and experimental design. Q Rev Biol 66:149-179

Kaska Y, Downie R, Tippett R, Furness RW (1998) Natural temperature regimes for loggerhead and green turtle nests in the eastern Mediterranean. Can J Zool 76: 723-729

Laurent L, Bradai MN, Hadoud DH, El Gomati HM, Hamza AA (1998a) Assessment of sea turtle nesting activity in 
Libya. Phase 3: survey of the coasts between the Tunisian border and Misratah. Final Report UNEP RAC/SPA, Tunis

Laurent L, Casale P, Bradai MN, Godley BJ and 14 others (1998b) Molecular resolution of marine turtle stock composition in fishery bycatch: a case study in the Mediterranean. Mol Ecol 7:1529-1542

Lazar B, Margaritoulis D, Tvrtkovic N (2004) Tag recoveries of the loggerhead sea turtle Caretta caretta in the eastern Adriatic Sea: implications for conservation. J Mar Biol Assoc UK 84:475-480

Manzella SA, Fontaine CT, Schroeder BA (1988) Loggerhead sea turtle travels from Padre Island, Texas to the mouth of the Adriatic Sea. Mar Turt Newsl 42:7

Margaritoulis D, Argano R, Baran I, Bentivegna F and 10 others (2003) Loggerhead turtles in the Mediterranean Sea: present knowledge and conservation perspectives. In: Bolten $\mathrm{AB}$, Witherington $\mathrm{B}$ (eds) Loggerhead sea turtles. Smithsonian Institution Press, Washington, DC, p 175-198

Mrosovsky N (1994) Sex ratios of sea turtles. J Exp Zool 270: $16-27$

Mrosovsky N, Baptistotte C, Godfrey MH (1999) Validation of incubation duration as an index of the sex ratio of hatchling sea turtles. Can J Zool 77:831-835

Owens DW, Hendrickson JR, Lance V, Callard IP (1978) A technique for determining sex of immature Chelonia mydas using a radioimmunoassay. Herpetologica 34: $270-273$

Rees AF, Margaritoulis D (2004) Beach temperatures, incuba-

Editorial responsibility: Otto Kinne (Editor-in-Chief),

Oldendorf/Luhe, Germany tion durations and estimated hatchling sex ratio for loggerhead sea turtle nests in southern Kyparissia bay, Greece. Testudo 6:23-36

Standora EA, Spotila JR (1985) Temperature dependent sex determination in sea turtles. Copeia 1985:711-722

Wibbels T (2003) Critical approaches to sex determination in sea turtles. In: Lutz PL, Musick JA, Wyneken J (eds) The biology of sea turtles, Vol II. CRC Press, Boca Raton, FL, p 103-134

Wood JR, Wood FE, Critchley KH, Wildt DE, Bush M (1983) Laparoscopy of the green sea turtle, Chelonia mydas. $\mathrm{Br}$ J Herpetol 6:323-327

Work TM (2000) Sea turtle necropsy manual for biologists in remote refuges. US Geological Survey, National Wildlife Health Center, Hawaii Field Station, Honolulu, HI

Wyneken J (2001) The anatomy of sea turtles. NOAA Tech Memo NMFS-SEFSC-470, Miami, FL

Yntema CL, Mrosovsky N (1980) Sexual differentiation in hatchling loggerheads (Caretta caretta) incubated at different controlled temperatures. Herpetologica 36:33-36

Zar JH (1999) Biostatistical analysis, 4th edn. Prentice-Hall, Upper Saddle River, NJ

Zbinden JA, Margaritoulis D, Arlettaz R (2006) Loggerhead sea turtle hatchling sex ratios from Zakynthos: small-scale differences might be crucial for the Mediterranean metapopulation. In: Demetropoulos A, Turkozan O (eds) Proc 2nd Mediterr Conf Mar Turtles, Kemer, May 2005 (in press)

Submitted: September 21, 2005; Accepted: February 13, 2006 Proofs received from author(s): October 10, 2006 